Maurer School of Law: Indiana University

Digital Repository @ Maurer Law

2006

\title{
Lost in Translation: The Economic Analysis of Law in the United States and Europe
}

Kenneth G. Dau-Schmidt

Indiana University Maurer School of Law, kdauschm@indiana.edu

Carmen L. Brun

Eversheds Sutherland

Follow this and additional works at: https://www.repository.law.indiana.edu/facpub

Part of the Comparative and Foreign Law Commons, and the Law and Economics Commons

\section{Recommended Citation}

Dau-Schmidt, Kenneth G. and Brun, Carmen L., "Lost in Translation: The Economic Analysis of Law in the United States and Europe" (2006). Articles by Maurer Faculty. 213.

https://www.repository.law.indiana.edu/facpub/213

This Article is brought to you for free and open access by the Faculty Scholarship at Digital Repository @ Maurer Law. It has been accepted for inclusion in Articles by Maurer Faculty by an authorized administrator of Digital Repository @ Maurer Law. For more information, please contact rvaughan@indiana.edu. 


\title{
Essay
}

\section{Lost in Translation: The Economic Analysis of Law in the United States and Europe}

\author{
KENNETH G. DAU-SCHMIDT* \\ CARMEN L. BRUN**
}

In this Essay, we examine the reasons why the economic analysis of law has not flourished in European countries as it has in the United States. In particular, we focus on three European countries-the United Kingdom, Germany, and France. We argue that differences in culture, the legal system, and the academy have led to differing degrees of success of the law and economics movement in each country. We speculate that, although there is currently less interest in the economic analysis of the law in Europe than in the United States, European interest could dramatically increase if scholars adopt more

* Willard and Margaret Carr Professor of Labor and Employment Law, Indiana University-Bloomington; Ph.D. (Economics), J.D., M.A., University of Michigan; B.A., University of Wisconsin.

** Snyder Visiting Scholar, Lauterpacht Centre for International Law-Cambridge University (Fall 2005); Associate, Sutherland, Asbill \& Brennan LLP-Washington, D.C.; J.D., M.B.A., B.A., Indiana University-Bloomington.

The authors would like to thank Tom Ulen, John Reitz, Nick Georgakopoulos, Amitai Aviram, and the rest of the participants in the Fourth Annual Meeting of the Midwestern Law and Economics Association for their useful comments on this Essay. The authors would especially like to thank Professor Elisabeth Zoller for taking the time to tutor the authors on French culture and law during her comparative law seminars at Indiana University-Bloomington and Université Panthéon-Assas (Paris II). Any insights the authors have captured regarding the French legal system and the French perspective on the economic analysis of law were gained through discussions with Professor Zoller. Any mistakes, of course, are ours alone. This Essay was originally written for a volume in honor of Professor Jost Delbrück, whose dedication to study and teaching on human rights has served as an inspiration for both authors. A version of it appears in WELTINNENRECHT-LIBER AMICORUM JOST DELBRÜCK, Veröffentlichungen des Walther-Schücking-Instituts für Internationales Recht an der Universität Kiel, Band 155, Seiten 131-56 (Klaus Dicke, Stephan Hobe, Karl-Urich Meyn, Anne Peters, Eibe Riedel, Hans-Joachim Schütz und Christian Tietje (Hrsg.), Berlin 2005). 
communitarian analyses aimed at analyzing legislative polices rather than judicial decisions.

I. INTRODUCTION .603

II. ECONOMIC ANALYSIS OF LAW IN THE UNITED STATES. .605

A. The American Culture and Legal System: The Protection of Rugged Individualism ............................605

B. The American Legal Academy ..................................608

C. Why the Economic Analysis of Law Has Succeeded in the United States

III. ECONOMIC ANALYSIS OF LAW IN EUROPE ..........................610

A. European Culture and Legal Systems: Cultured Collectivism

1. The United Kingdom: A Proud Tradition of Collective Laissez-Faire

2. Germany: Human Rights in a Well-Ordered System of Co-Determination

3. France: "Liberté, Egalité et Fraternité!" dans une Société de Confrontation et de Conflit

B. The European Academy...........................................614

C. Why Europe Has Not Been Fertile Ground for the Economic Analysis of Law...

IV. THE FUTURE OF LAW AND ECONOMICS IN EUROPE .619

\section{INTRODUCTION}

The economic analysis of law enjoys a long and proud tradition in the United States and is firmly rooted in its legal system. ${ }^{1}$ The growth of the "law and economics movement" in the American legal environment has been compared to the release of the rabbit in Australia: "[E]conomics found a vacant niche in the intellectual ecology" of the law and rapidly filled it."2 Although initially confined to areas like antitrust and regulated industries, thanks to the pioneering scholarship of academic luminaries such as Gary Becker,

1. The beginning of the modern law and economics movement in the United States is generally traced to the seminal articles of Ronald Coase and Guido Calabresi in the early 1960s. See Ronald H. Coase, The Problem of Social Cost, 3 J.L. \& ECON, 1 (1960) (using economic principles to analyze nuisance law); Guido Calabresi, Some Thoughts on Risk Distribution and the Law of Torts, 70 YALE L.J. 499 (1961) (discussing the distribution of economic losses in tort law).

2. ROBERT COOTER \& ThOMAS Ulen, LAW AND ECONOMics 3 (3d ed. 2000). 
Ronald Coase, Richard Posner, and Guido Calabresi, the American law and economics movement has permeated almost every nook and cranny of the American legal landscape, including criminal law, family law, employment discrimination, and procedural law. ${ }^{3}$

If the success of the application of economic analysis to legal problems in the United States can be compared to that of the rabbits released in Australia, the law and economics movement in Europe might best be compared to the experience of the camels that were released into the American southwest. ${ }^{4}$ Although the economic analysis of law has been of some interest to European scholars, it seems curiously out of place in their work and, so far, the discipline has not been successfully transplanted to the European academic ecosystem. ${ }^{5}$ Indeed, Professor Dau-Schmidt's experience has been that the primary interest of European legal scholars in the economic analysis of law is for use as a window into the American legal mind, rather than for purposes of applying the same principles in the analysis of European laws. The impact of the economic analysis of law on European legislation and court decisions has been negligible. ${ }^{6}$ Although it appears that the movement is currently under-appreciated in Europe, the authors believe there is tremendous opportunity for its future application on that continent.

This Essay will examine the reasons why the economic analysis of law has not flourished in European countries as it has in the United States. In particular, this Essay will focus on three European countries - the United Kingdom, Germany, and France. Each of these countries has a different culture, legal system, and legal

3. Richard A. Posner, The Future of the Law and Economics Movement in Europe, 17 INT'L REV. L. \& ECON. 3, 4 (1997).

4. Cf. Robert Berg, Camels West, SAudi ARAMCo WORLD, May-June 2002, available at http://www.saudiaramcoworld.com/issue/200203/camels.west.htm. Camels were brought to the United States in the mid-nineteenth century. After they were employed in a number of enterprises, including the short-lived U.S. Army Camel Corps, they were released into the wild. They failed to adapt successfully to their new environment and eventually disappeared from the landscape. Id.

5. See Lionel Montagné, Law and Economics in France, in 1 ENCYCLOPEDIA OF LAW AND ECONOMICS 150, 150-51 (Boudewijn Bouckaert \& Gerrit De Geest eds., 2000) (examining the reasons why law and economics has not been thoroughly embraced in the French legal system), available at http://encyclo.findlaw.com/0325book.pdf; see also Éric Brousseau, Did the Common Law Bias the Economics of Contract . . . and May It Change?, in LAW AND ECONOMICS IN CIVIL LAW COUNTRIES 79 (Bruno Deffains \& Thierry Kirat eds., 2001) (arguing that both civil law doctrine and the economics of contract law could benefit by cross-fertilization), available at http://www.brousseau.info/en/publications/index. php?req=29; Ugo Mattei \& Robert Pardolesi, Law and Economics in Civil Law Countries: A Comparative Approach, 11 INT'L REV. L. \& ECON. 265, 266 (1991) (arguing that the economic analysis of law could easily be transplanted into civil law countries).

6. Christian Kirchner, The Difficult Reception of Law and Economics in Germany, 11 INT'L REV. L. \& ECON. 277, 277 (1991). 
academy, which have led to different degrees of success in the application of economic principles in the analysis of law.

\section{ECONOMIC ANALYSIS OF LAW IN THE UNITED STATES}

The economic analysis of law has played a significant role within the U.S. legal academy as well as in the development of the country's legal system. The U.S. legal academy has engaged in a dynamic interdisciplinary debate for decades - the most notable example of this process is the law and economics movement. ${ }^{7}$ Scores of articles have been written analyzing American legal doctrines and statutes from an economic perspective. ${ }^{8}$ Proponents of the economic analysis of law hold prestigious appointments to the federal bench, including Court of Appeals Judges Richard Posner and Frank Easterbrook, and Supreme Court Justices Antonin Scalia and Stephen Breyer. ${ }^{9}$ Why has the economic analysis of law prospered in the United States? An examination of the American culture, legal system, and legal academy yields many insights.

\section{A. The American Culture and Legal System: The Protection of Rugged Individualism}

Forged on the North American frontier, American culture is defined by the rugged individualism and autonomy of classic Lockean liberalism. Liberalism holds that citizens are inevitably self-interested. ${ }^{10}$ Molding the citizenry towards a common good is a waste of time because one cannot remove self-interest, and in fact, diversity of interest precludes anything like a common good. The goal of classic liberalism is to encourage citizens to pursue their own views and goals. ${ }^{11}$ Liberalism also holds that individuals are

7. See Richard A. Posner, Law and Economics in Common-Law, Civil-Law, and Developing Nations, 17 RATIO JURIS 66, 66 (2004); see also Thomas S. Ulen, A Crowded House: Socioeconomics (and Other) Additions to the Law School and Law and Economics Curricula, 41 SAN DIEGo L. REV. 35, 35-37 (2004); Robert C. Ellickson, Bringing Culture and Human Frailty to Rational Actors: A Critique of Classical Law and Economics, 65 CHI.-KENT. L. REV. 23, 29-30 (1989).

8. See Posner, supra note 7 , at 66 n.1.

9. Cento Veljanovski, The Economics of Law: An Introductory TeXt 26 (1990).

10. See John Locke, The Second Treatise of Government (An Essay Concerning THE TRUE ORIGINAL, EXTENT AND END OF CiVIL GOVERNMENT) AND A LETTER CONCERNING TOLERATION 64 (J.W. Gough ed., Basil Blackwell \& Mott, Ltd. 1966) (1690) ("[Y]et men, being biased by their interest ....").

11. See id. at 63-66. 
endowed with certain natural rights that are reserved by the individual in the social contract and not dependent on the government for their legitimacy. ${ }^{12}$ This view of the social contract differs from the French version, which will be discussed shortly, in which all individual rights are given up to the state and then returned to the individual. ${ }^{13}$ Moreover, since our experience as a British colony, Americans have been "suspicious" of big government and, therefore, strongly believe in limited government and decentralized decisionmaking. ${ }^{14}$

These features of American culture make the United States a receptive environment for application of economic analysis to law. Neoclassical economic analysis is based on individual, rational decision-making, ${ }^{15}$ akin to the individual decision-making revered by classic liberalism. Moreover, the logic of neoclassical economic analysis supports decentralized decision-making by market participants, with minimal government interference, as a means of maximizing efficiency. ${ }^{16}$ This logic is consistent with both the American distrust of government power and our constitutional system of protecting individual rights from government intrusion. Accordingly, it is not surprising that legal problems of interest to Americans are readily amenable to economic analysis.

Consistent with Lockean liberalism, the protection of individual rights in America is a key feature of the U.S. Constitution - as most notably exhibited in the Bill of Rights. The government is prevented from infringing upon these individual rights and, in the event they are infringed, the courts must decide their limits and the means to protect them properly. As a result of Americans' suspicion of big government, the U.S. Constitution created three separate and distinct branches of the federal government, each enjoying relatively equal distribution of power through a system of checks and balances. This system was established to protect individual rights-and the states-from encroachment by the federal government. The judiciary enjoys a relatively powerful role due to its ability to review legislation and strike down that which it deems to violate the Constitution. ${ }^{17}$

12. See id. at 43.

13. See infra Part III.A.3.

14. See Derek BoK, The State of the Nation: Government and the Quest for a BETTER SOCIETY 11 (1996).

15. See CoOTer \& Ulen, supra note 2, at 10-12; A. Mitchell Polinsky, AN INTRODUCTION TO LAW AND ECONOMICS 10 (2d ed. 1989); RICHARD A. POSNER, ECONOMIC ANALYSIS OF LAW 4 (6th ed. 2003).

16. See POSNER, supra note 15 , at 3.

17. See Marbury v. Madison, 5 U.S. (1 Cranch) 137 (1803) (establishing the judiciary's position as the final arbiter of the constitutionality of legislation). 
The relative strength and fluidity of the American judiciary seem to have provided significant impetus for the growth of the economic analysis of law in the American experience. ${ }^{8}$ Given their position of relative strength in our system of checks and balances, American judges are allowed, perhaps even compelled, to be more creative than their European counterparts. Even in comparison with their British common law cousins, American judges are "considered far more adventurous." 19 Furthermore, decisions by U.S. judges are less likely to be overturned by subsequent legislation. The American system of checks and balances presents more obstacles to legislation designed to countermand a court decision than the European parliamentary systems. ${ }^{20}$

Moreover, the legal profession is extremely fluid. In the United States, it is

altogether natural for a lawyer in the course of his career to be a professor, a practicing attorney, a judge, and even a politician .... [T] his fluidity of roles has enabled a number of law professors identified with the law and economics movement to become consultants, practitioners, government officials, judges, and even Supreme Court Justices. ${ }^{21}$

Some of the movement's best-known scholars, including Richard Posner and Guido Calabresi, have been appointed to the bench. $^{22}$ This constant movement of people within the American legal profession facilitates the cross-fertilization of law by other disciplines, most notably by economics. ${ }^{23}$

America's common law system is also widely believed to have facilitated the growth of the law and economics movement. It is presumed that a common law system is more efficient than a civil

18. See Posner, supra note 3 , at 3-4.

19. Robert D. Cooter \& Tom Ginsburg, Comparative Judicial Discretion: An Empirical Test of Economic Models, 16 INT'L REV. L. \& ECON. 295, 295 (1996); see also, Nicholas L. Georgakopoulos, Discretion in the Career and Recognition Judiciary, 7 U. CHI. ROUNDTABLE 205 (2000) (using a comparative empirical analysis to establish that American judges exercise greater discretion than their European siblings).

20. Under the American system of checks and balances, laws must be approved by the House, Senate, and President to become law, and they are subject to filibuster. Under the British parliamentary system, laws can be passed merely with the approval of one house of parliament. The German parliamentary system has two houses and the French PresidentialParliamentary system has two houses and holds the possibility of a split in party allegiance between the President and the Parliament; however, in practice both of these systems generally offer an easier time for the passage of corrective legislation than the American system of checks and balances. See Cooter \& Ginsburg, supra note 19, at 295-96.

21. Posner, supra note 3, at 3-4; see also Posner, supra note 7, at 76-77.

22. VELJANOVSKI, supra note 9 , at 26.

23. Posner, supra note 3 , at 3-4. 
law system because

the common law is designed to give effect to private bargains with minimum active interference from the state ... and ... common law rules tend to become precedential only to the extent that they are efficient [because] . . . more efficient rules are upheld while less efficient ones are overruled. ${ }^{24}$

Moreover, the role of the judge in the common law system is more extensive than that in a civil law system. Under a common law system, judges interpret statutes and constitutions while "discovering" the common law that prevails in the absence of relevant legislation. Under a civil law system, the judge is merely the "mouthpiece for the law," interpreting the legal rights and relationships that are established by the legislature in the code. ${ }^{25}$

\section{B. The American Legal Academy}

The American legal academy combines student graduate study with a professionally trained professorate in a way that provides little cover for an entrenched philosophy of legal discipline. In the United States, students typically undertake study for a threeyear graduate legal degree (J.D.) after they have already successfully completed a four-year undergraduate degree. Traditionally, American law professors had no education beyond the same threeyear graduate degree conferred upon all attorneys and were drawn from legal practice. The demands of law school hiring committees are changing in this regard, in no small part due to the success of the law and economics movement. ${ }^{26}$ However, at the time of the rise of the law and economics movement in the United States during the 1960 s and 1970s, the American academy combined a relatively welleducated student body that had been exposed to a variety of academic disciplines with a faculty that had a relatively small investment in any particular academic perspective or school of thought. This combination provided fertile ground for the spread of economic analysis in the American academy in that it provided both students

24. Herbert Hovenkamp, The First Great Law \& Economics Movement, 42 STAN. L. REV. 993, 1015 (1990).

25. See M. De Secondat, Baron de Montesquieu, 1 The Spirit of Laws 170 (Thomas Nugent trans., George Bell \& Sons 1906).

26. The attainment of an additional graduate degree in law, or even a Ph.D. in another discipline, is an increasingly important credential for young legal academics in America, while prior legal practice has declined in importance. See Thomas S. Ulen, The Unexpected Guest: Law and Economics, Law and Other Cognate Disciplines, and the Future of Legal Scholarship, 79 CHI.-KENT. L. REV. 403, 414-15 (2004). 
who had the undergraduate preparation for instruction in such theory and a professorate who were not overly wedded to existing legal philosophy.

Further undermining the entrenchment of the academic status quo in the United States is the fact that American legal scholarship is published in an exceedingly large number of primarily student-edited journals. Because the vast majority of U.S. journals are studentedited, legal scholars do not need to convince a fellow professor, steeped in the arguments of the prevailing legal discipline, that an article is important in order to get it published. Only student editors need be convinced. Articles in student-edited journals are published not because they support the traditional legal discipline but because they are interesting, novel, or controversial. Accordingly, it is relatively easy for new ideas from a variety of disciplines to find their way into the American legal literature.

Finally, just prior to the rise of the law and economics movement in the United States, the American legal academy experienced a void in legal theory. During the middle of the twentieth century, the logic of legal formalism gave way to the empirical demands of legal realism in the United States. ${ }^{27}$ Rather than divining the inherent logic of the law from disparate appellate opinions, the American legal academy became increasingly concerned with documenting the reality of the law in practice. At the same time, scholarship in philosophy undermined the traditional normative underpinnings of American legal thought. ${ }^{28}$ This decline in formalism and traditional normative theory created an opportunity for the rise of the economic analysis of law in the American legal academy. ${ }^{29}$ Not only was the structure of the American legal academy amenable to change, but the American legal academy felt

27. See Arthur Allen Leff, Economic Analysis of Law: Some Realism About Nominalism, 60 VA. L. REV. 451, 453-54 (1974).

Once upon a time there was Formalism. The law itself was a deductive system, with unquestionable premises leading to ineluctable conclusions. It was, potentially at least, all consistent and pervasive ....

Then, out of the hills, came the Realists. ... they were much more interested in the way law actually functioned in society ... . The critical questions were henceforward no longer to be those of systematic consistency, but of existential reality.

Id.; see also Ulen, supra note 26, at 403.

28. Leff, supra note 27, at 454-55.

29. See Ugo MatTeI, Comparative Law and Economics 85 (1997).

[O]ne of the reasons for the success of law and economics in America was the need for 'reconstruction' after years of realist jurisprudence had reduced legal scholarship to little more than a sterile commentary on case law. Law and economics was seen as a tool for thinking about the law in broad theoretical terms, giving scholars back their role as social engineers.

Id. (citing BruCe A. ACKerman, ReCONSTRUCTING AMERICAN LAW (1983)). 
the need to borrow from economics and other disciplines in order to fill the gaps in its own disciplinary perspective. Among all of the disciplines that the law has borrowed from, economics is the most important. "The moving force of this change is not all of the "law and' developments of the last twenty years but one particularly-law and economics." 30

\section{Why the Economic Analysis of Law Has Succeeded in the United States}

The American cultural and legal landscapes have proven fertile ground for the law and economics movement. The neoclassical model of individual rational decision making through decentralized markets strikes a harmonious cord with American individualism and our distrust of centralized government power. Moreover, our system of governmental checks and balances and common-law adjudication makes for a relatively strong and adventuresome judiciary that is more likely to be subject to evolutionary pressure towards efficient legal rules or to decide cases on the basis of public policy. Finally, the history and structure of our legal academy allows for a wide-open scholarly debate that incorporates facets from many disciplines. Thus, it is not surprising that the careers of the greatest theorists in the law and economics movement, including Ronald Coase, Guido Calabresi, and Richard Posner, have taken place in the United States.

\section{ECONOMIC ANALYSIS OF LAW IN EUROPE}

Although Europeans are curious about the law and economics movement, its impact on their legal environment has been comparatively slight, especially in the civil law countries. Few European universities offer classes strictly devoted to the study of the economic analysis of law. ${ }^{31}$ Additionally, the study of law and economics is not generally incorporated into traditional law courses. $^{32}$ Articles employing the economic analysis of law are

30. Ulen, supra note 26 , at 405 .

31. In Germany, for instance, only law schools in Hamburg, Munich, Oldenburg, and Hanover offered courses in law and economics in 1993. Thomas Henne, Environmental Policy in Germany and the United States, 51 AM. J. COMP. L. 207, 226 n.84 (2003) (reviewing Susan Rose-Ackerman, Controlling EnVIRonMental Policy: The Limits of PUblic LAW IN GERMANY AND THE UNITED STATES (1995)).

32. Cf. Kirchner, supra note 6, at 279-80 (discussing the relatively minor influence of the economic analysis of the law as of 1991 in Germany). 
relatively rare in the European academy, and there is only one European journal dedicated solely to the economic analysis of law. ${ }^{33}$ Economic analysis is fairly uncommon in European cases outside its traditional stronghold of antitrust, and there are no comparable judicial appointments of law and economics scholars to the bench as there has been in the United States. Of the three countries profiled in this Essay, law and economics has been most successful in England and least successful in France. An examination of the cultures, legal systems, and legal academies of these various countries, in light of our analysis of the success of law and economics in the United States, will yield insight into these observations.

\section{A. European Culture and Legal Systems: Cultured Collectivism}

1. The United Kingdom: A Proud Tradition of Collective Laissez-Faire

The British have a strong class hierarchy. Unlike in the United States, where wealth and social stature can be attained through individual achievement, wealth and social stature in England are traditionally determined at birth. ${ }^{34}$ Class organization is strong within, but not between, the classes. The organized working class has little trust in the upper class, which includes much of the British legislature and judiciary. ${ }^{35}$

The British are more invested in history and tradition than Americans, even though both countries follow the common law system. Unlike the United States, the United Kingdom has no written constitution. The British constitution is not the outcome of a revolution as in France and the United States. Instead, it is a historical constitution to which only gradual changes have been made over centuries. The British have always looked to their inheritable past and time-honored traditions to determine the scope of their laws. ${ }^{36}$

33. Posner, supra note 7 , at 66.

34. Kenneth G. Dau-Schmidt, Labor Law and Industrial Peace: A Comparative Analysis of the United States, the United Kingdom, Germany, and Japan Under the Bargaining Model, 8 TUL. J. INT'L \& COMP. L. 117, 137 (2000) (citing HENRY BROWN, THE ORIGINS OF TRADE UNION POWER 208-09 (1983)).

35. Id.

36. See Edmund Burke, Reflections on the Revolution in France 27-28 (J.G.A. Pocock ed., 1987) ("The [Glorious] Revolution [of 1689] was made to preserve our ancient, indisputable laws and liberties and that ancient constitution of government which is our only security for law and liberty .... All the reformations we have hitherto made have proceeded upon the principle of reverence to antiquity."); see also COLIN TURPIN, BRITISH 
Parliamentary sovereignty reigns in the United Kingdom. There, Parliament is comprised of a compound body made up of the Crown, the Lords, and the Commons. ${ }^{37}$ Nothing is above Parliament. Parliamentary sovereignty has facilitated a strong legislature at the expense of the executive and judiciary; consequently, even though the British have a common law system, the judges have only a limited role in the interpretation of the law. Generally, British courts may only interpret Acts of Parliament and do not have the power to declare an Act unconstitutional. ${ }^{38}$ This is an important distinction from U.S. courts, which have the authority to declare any statute unconstitutional.

\section{Germany: Human Rights in a Well-Ordered System of Co- Determination}

Due to their experience in World War II, modern Germans place the utmost importance on human rights and collective cooperation. German law values people as humans rather than commodities. Moreover, the Germans have organized their society in a way that allows for the state mediation of interests among groups. For instance, Germany regulates its industrial relations system to encourage nationwide collective bargaining between labor and management in an environment of cooperative consultation and exchanges of information. ${ }^{39}$ The net result is a more cooperative and productive system of industrial relations, with fewer work stoppages than in the United States and the United Kingdom. ${ }^{40}$

While Germany does have a separation of powers doctrine, historic events have modified this doctrine to grant more power to the legislature, at the expense of the executive and the judiciary. Although the German judiciary is independent, its discretion is generally limited to the interpretation of the civil code enacted by the legislature. "German law courts tend to stay within the boundaries

Government ANd the Constitution: TeXt, Cases and Materials 4-5, 11 (5th ed. 2002).

37. See A.V. Dicey, INTROdUCtION TO THE STUdy OF THE LAW OF THE CONSTITUTION 407 (10th ed. 1959) (1885); see also Human Rights Act, 1998, c. 42 (Eng.), available at http://www.hmso.gov.uk/acts/acts 1998/80042--a.htm\#1.

38. See Lesley Dingle \& Bradley Miller, A Summary of Recent Constitutional Reform in the United Kingdom, 33 INT'L J. LEGAL INFO. 71, 75 (2005). As a member of the European Union, however, Britain's courts must now reconcile any Acts of Parliament enacted subsequent to January 1, 1973 that conflict with European Court of Justice interpretations of EU law in force in the United Kingdom. Id. Judges may also fill in holes in the British law left by Parliament. See Turpin, supra note 36, at 48.

39. Dau-Schmidt, supra note 34, at 146.

40. Id.

41. See Kirchner, supra note 6 , at 283. 
of traditional legal reasoning to keep their factual autonomy vis-à-vis the legislature." 42 To invite frequent legislative countermands would undermine the independent authority of the courts in the eye of the public. Thus, like their British counterparts, German judges are limited in their ability to bring external value judgments into their decision making because of the ease with which the legislature can overturn a judge-made legal rule. ${ }^{43}$

Not only does the threat of parliamentary override limit the role of German judges but the very nature of a civil law system also narrows judicial discretion. Under a common law system, the "judge is somehow expected to judge" whereas in civil law systems, the code is expected "to have already judged." 44 Civil law "judges are not to be the cheerleaders for capitalism" but, instead, they should passively and mechanically enforce the law without regard to the wealth or social class of the parties. ${ }^{45}$ Values of fairness and equity tend to be more important under civil law systems than the efficiency that often influences U.S. common law decisions. ${ }^{46}$

3. France: “Liberté, Egalité et Fraternité!" dans une Société de Confrontation et de Conflit

The effect of the French Revolution was to overthrow the class-based system and to create national sovereignty. ${ }^{47}$ Unlike England, the French cultural and legal landscape is not predicated on class. The French do not focus on individual self-interest but rather the common good of society. "[L]aws are supposed to primarily organize relationship [sic] among people in order to avoid negative externalities and to ensure public order." 48

42. Id. at 285 .

43. Id.

44. Mitchel de S.-O.-1'E. Lasser, Comparative Law and Comparative Literature: $A$ Project in Progress, 1997 UTAH L. REV. 471, 471 (quoting Interview with Jean-François Lyotard in New Haven, Conn. (Jan. 1992)).

45. Posner, supra note 7, at 76.

46. Horacio Spector, Fairness and Welfare from a Comparative Law Perspective, 79 CHI.-KENT. L. REV. 521, 539 (2004). In contract disputes, French courts are less willing to allow the parties to renegotiate the terms of a contract and are more willing to grant specific performance over efficient breach because these doctrines will guarantee the fairness of the contract. By contrast, American courts are more flexible and apply the doctrine that will provide the most efficient outcome. See Brousseau, supra note 5, at 4.

47. A nation "is a body of associates, living under a common law, represented by the same legislature, etc." Emmanuel Joseph Sieyès, What is the Third Estate?, in PoliticaL WRITINGS 92, 97 (Michael Sonenscher trans., 2003).

48. Brousseau, supra note 5, at 5 . 
The French cultural and legal landscape has been shaped by Jean-Jacques Rousseau's theory of the social contract. ${ }^{49}$ Under Rousseau's social contract, all people form an association by giving to the community all of their individual rights. No rights are reserved to the individual. In return, the community provides order and gives back these rights to its citizens guaranteeing the rights in the social contract. The community defends and protects the people and their goods. ${ }^{50}$ The sovereign-in this case, the nation-creates an ordering system to determine what is right for the common good of the community. ${ }^{51}$ Because law is an expression of the general will, it is not subject to judicial review. It is the law that decides the division of rights and not the courts.

France, like Germany, is a civil law system. Common law was shunned because it "was identified with the losing side" of the French Revolution. ${ }^{52}$ Judges were viewed with suspicion because they had upheld the class-based ancien régime by regularly overruling bourgeois reforms. The "revolutionaries .... wanted to uproot 'medieval' practices and replace them with 'rational' ones. The revolutionaries proclaimed that law derived its authority from the popular will as expressed through legislators, not from social norms as found by judges."53

\section{B. The European Academy}

In general, European legal education combines undergraduate study for future practicing lawyers with extensive academic preparation for the professorate. In France and Germany, a law diploma is an undergraduate degree taught by highly professional scholars with graduate degrees beyond the initial law degree. Although the traditional method of legal education in the United Kingdom is by reading for the bar, recently the British have adopted legal education through formal undergraduate education at degreegranting institutions. European law professors, on the other hand, undergo not only years of undergraduate study, but also years of practicum and graduate study, emerging from the end of a long process with degrees and training that would be the American

49. See JeAn-JacQues Rousseau, On THE Social Contract (Donald A. Cress ed. \& trans., 1987).

50. Id. at $23-25$.

51. Id. at 25-26.

52. Robert D. Cooter, Decentralized Law for a Complex Economy: The Structural Approach to Adjudicating the New Law Merchant, 144 U. PA. L. REV. 1643, 1650 (1996).

53. Id. at $1650-51$. 
equivalent of a Ph.D. in law. As a result, in comparison with their American colleagues, European law professors teach students who have less preparation in other disciplines, and European professors are more heavily invested in existing legal scholarship.

Institutional features of the European academy further entrench disciplinary practices and ideals. Publication by European legal scholars is mostly in faculty-edited books or journals. There are fewer European journals overall and only one European journal is dedicated solely to the economic analysis of law. ${ }^{54}$ Very few of the general journals publish articles by law and economics scholars. ${ }^{55}$ Tenure, at least in France, is granted on a national, rather than an institutional, basis. Review is undertaken through a unitary national process and review committee. As a result, new approaches in the analysis of law must receive approval from scholars invested in the existing body of scholarship before they can be published or earn their author tenure.

Finally, formalism did not suffer the same precipitous decline in Europe that it did in the United States. The conception of "legal science" in continental Europe consists of a massive body of legal scholarship that can trace its roots all the way back to Roman law and which is considered such an important backdrop for the drafting of modern legal codes that all legal arguments generally start, and finish, with this body of accumulated wisdom. ${ }^{56}$ Although the legal realist movement made a strong challenge to formalism in Germany in the 1920s and 1930s, the movement became associated with the Nazi regime and accordingly suffered in its consideration by modern European legal theorists. 57 European scholars of course recognize that strict formalism is not a completely accurate view of the development of law, but because this school of thought did not suffer the same precipitous decline it suffered in America, there has been no similar void in the discipline of law for the law and economics movement to fill. European legal academic institutions are less open to change because the law is already an established discipline and scholars are not necessarily looking to supplement it with other disciplines. Accordingly, in Europe, the discipline of law has suffered less of a crisis of confidence, and there has been less need for legal theorists to borrow from other disciplines, including

54. Posner, supra note 7 , at 66 .

55. See Henne, supra note 31 , at $226 \mathrm{n} .85$ (discussing the situation in Germany).

56. See generally Mathias Reimann, Nineteenth Century German Legal Science, 31 B.C. L. REV. 837 (1990).

57. See Robert Cooter \& James Gordley, Economic Analysis in Civil Law Countries; Past, Present, Future, 11 INT'L REv. L. \& ECON. 261, 262 (1991) (citing Kirchner, supra note 6 , at 284). 
economics.

\section{Why Europe Has Not Been Fertile Ground for the Economic Analysis of Law}

The relative lack of success of the economic analysis of law in Europe to date can be traced to characteristics of European culture, legal systems, and the European legal academy.

In general European culture is more communitarian and steeped in history and tradition than American culture. European society is more state-oriented and less trusting of the market. ${ }^{58}$ As a result, the analysis of legal problems from the perspective of individual rational actors seems curious from the perspective of many Europeans. British culture organizes its society and law more around the traditional interaction of social groups than rational individual action. For example, for years the British tolerated one of the most inefficient industrial relations systems in the industrialized world, based on work days lost to industrial strife, due to their acceptance of a tradition of class conflict through industrial strife. ${ }^{59}$ Similarly, the Germans' commitment to human rights causes them to disdain express discussions of the value of human life and the efficient level of medical care or regulation. ${ }^{60}$ However, perhaps the French pose the best example of a communitarian society with their commitment to national sovereignty and the social contract as envisioned by JeanJacques Rousseau. The French conception that the nation-state adopts a system of order and law is inconsistent with the assumptions of the normative equality among all activities and the valuation of entitlements based on willingness to pay implicit in the neoclassical economic model. ${ }^{61}$ Moreover, the French do not focus on individual

58. See John C. Reitz, Political Economy as a Major Architectural Principle of Public Law, 75 TUL. L. REV. 1121, 1130 (2001) (discussing state orientation in Germany and France).

59. Dau-Schmidt, supra note 34, at 139-40 (arguing that because of Britain's social class structure and the perceived lack of community interest among the classes, the working classes have traditionally been unwilling to entrust labor relations reforms to Parliament, which they perceive as upper class. Thus, for a major industrial country, labor relations in Great Britain remain largely unregulated).

60. This statement is based on Professor Dau-Schmidt's seminar discussions with German students at the Institut für Internationales Recht, Christian-Albrechts-Universität on the value of human life and efficient safety regulation.

61. For example, in his lectures at Université Panthéon-Assas (Paris II) concerning the Coase theorem, Professor Dau-Schmidt found that his French students were particularly skeptical of Coase's claim of the reciprocity of harm. See R. H. Coase, The Problem of Social Cost, 3 J.L. \& ECON. 1, 3-4 (1960). Similarly, Gary Becker's notion of the efficient level of crime based on an implicit valuing of the benefits of crime to the criminal makes no sense to the French. See Gary S. Becker, Crime and Punishment: An Economic Approach, 
exchange and efficiency but rather on fairness and equity. "The rationality of the economic agent who is perfectly aware of prices, and operates calculated choices in order to maximize his pleasure at the least cost, is a disconcerting model for one who searches solutions [sic] in equity and not in utility." 62

European legal systems also are less amenable to the economic analysis of law than the American system. The European parliamentary systems allocate more power to the legislature, and less to the judiciary, than the American system. Under British parliamentary sovereignty, the word of Parliament is supreme. Similarly, Germany's separation of powers doctrine allocates power to the legislature at the expense of the judiciary. Although the German judiciary is independent, it is very careful not to "invoke external values or consideration of public policy" and risk losing its autonomy from the legislature. ${ }^{63}$ As a result, the use of social sciences has met with great resistance when such arguments have been raised in legal interpretation. ${ }^{64}$

The European civil law systems generally provide a more limited role for judges. "Civil law reasoning typically starts from abstract premises and concepts and, therefore, gives little room to the kind of consequentialist, forward-looking reasoning on which law and economics relies." 65 Ostensibly, civil law judges only interpret the law because the law itself, as written by the nation, has already judged. ${ }^{66}$ Although European scholars recognize that in reality even merely "reading" a statute can involve important policy decisions, the rhetoric of European legal practice in the civil systems is that all of the policy decisions have already been addressed by the legislature. ${ }^{67}$

76 J. POL. ECON. 169 (1968).

62. Montagné, supra note 5 , at 154 .

63. Kirchner, supra note 6, at 285.

64. Id. at 284-85.

65. Spector, supra note 46 , at 536 .

66. de S.-O.-l'E. Lasser, supra note 44, at 471 (quoting Interview with Jean-François Lyotard, in New Haven, Conn. (Jan. 1992)).

67. Dawson and Merryman believe that French judges go beyond strict formalism in their decisions but do so:

... behind the scenes, behind the veil of the formal French judicial decision:

French judges do approach cases with a certain pragmatic concern for realism, equity, and justice. On the other hand, the dominant, rigid French conception of adjudication requires that French judges mask their pragmatism, forcing them to operate under the table. This cuts French judges off from each other, preempting any reasoned and collective application of caselaw techniques. The result is a combination of frustratingly formalist decision making and closeted, individual, ad hoc, unprincipled, and unconstrained judicial pragmatism.

Id. at 473 (citing JOHN P. SAWSON, THE ORACLES OF THE LAW 375, 409-10 (1968); JOHN H. MERRYMAN, THE CIVIL LAW TRADITION: AN INTRODUCTION TO THE LEGAL SYSTEM OF WESTERN EUROPE AND LATIN AMERICA 151 (1969)). 
As a result, express policy-based arguments, like those used in economic analysis, generally are not welcome. Even though the British have a common law system that is the precursor of our own, the role of judges is more limited in the British system. Because of parliamentary sovereignty, judges are less likely to be adventurous and stray too much from time-honored traditions. ${ }^{68}$ They tend to rely more on the doctrine of stare decisis than their American common law counterparts, which leaves little room for policy analysis. ${ }^{69}$

Moreover, the relationship of the judiciary to practitioners and academics in Europe, and the lack of fluidity among these three forms of practice, may also contribute to the slow growth of the law and economics movement in Europe. The British legal profession "has been notoriously unwilling to admit the relevance of social science" to the discipline. 70 "The English legal fraternity is wary of theory, contemptuous of experts and academics, and reluctant to accept the idea that other disciplines have something valuable to say about "law." 71 In Germany, the legal academy is under the influence of the judiciary. The German Ministry of Justice limits the number of students admitted to the study of law, writes and administers the state law exams for admission to practice, and supervises the training of law students during their apprenticeships after the first state exam. ${ }^{72}$ The German judiciary's cautionary relationship with the social sciences has prevented economic analysis from becoming an integral part of their legal academy. ${ }^{73}$ Lastly, a European legal scholar is unlikely to move from professor to practicing attorney, to judge, and to legislator. In Germany and France, for instance, the judiciary is a separate profession. "The isolation and the relative political impotence of European judiciaries have contributed to their formalist approach, in which law is conceived of as a technical, autonomous discipline sealed off from other fields, such as economics."74

Finally, the structure of the European legal academy has been less amenable to the growth of the law and economics movement in

68. Cooter \& Ginsburg, supra note 19, at 295.

69. Spector, supra note 46 , at 537 .

70. VELJANOVSKI, supra note 9, at 11 (quoting A.J. Ogus \& G. Richardson, Economics and the Environment: A Study of Private Nuisance, 36 CAMBRIDGE L.J. 284, 284 (1977)).

71. Id. at 12 .

72. See Kirchner, supra note 6, at 284; see also Philip Leith, Legal Education in Germany: Becoming a Lawyer, Judge, and Professor, 4 WEB J. CURRENT LEGAL IsSUES 34, 9 (1995), available at http://webjcli.ncl.ac.uk/articles4/leith4.html. "The Ministry of Justice has an important part in the education of lawyers. Some might say that it has a more important role than that of many law professors who ... have no direct input to the examination process which will award degrees to students." Id. at 4-5.

73. See Kirschner, supra note 6, at 284 (discussing the slow adoption of sociology).

74. Posner, supra note 3 , at 5. 
Europe. The Europeans are heavily invested in law as an autonomous discipline and are quite happy with the academic product they produce. Although there is certainly interest in interdisciplinary research, the Europeans perceive no intellectual void or disciplinary crisis of confidence that they must fill with the economic analysis of law. Moreover, the European systems of publication in faculty-edited journals and national tenure help to reinforce the entrenched academic establishment. In order for new methods of analysis to make it into European scholarship, they have to gain at least some acceptance by academics who have built their careers on the status quo.

\section{THE FUTURE OF LAW AND ECONOMICS IN EUROPE}

Although the economic analysis of law may never be as important to Europeans as it is to Americans, it undoubtedly has applicability to European legal problems and potential to grow in its importance. No civil code is without its flaws. Scholars have long known that "the official and perfectly formalist conception of passive adjudication on the basis of the unproblematic application of the Codes' grammar is . . . no longer . . . tenable . . ."75 Civil law judges often have to fill these holes in the code with policy-based rules, although this process is often hidden from public view. Moreover, civil law systems increasingly rely on case law as well as statutes and regulations outside of the code to resolve disputes. ${ }^{76}$ Economic analysis can be a valuable tool in making such decisions.

If law and economics is to be accepted in European countries, especially in those where the judiciary is not on equal footing with the legislature, then the economic analysis of law must permeate not only judicial interpretation but also the legislation. Although it is true that even civil law judges inevitably make policy decisions in reading the code and deciding cases, within the European legal environment arguments that present express policy considerations are more appropriately made to the legislature. If economic analysis of law is openly considered and applied by the legislature, then these arguments will become important to European judges and academics.

The economic analysis of law may also become more important to Europeans as the European Union continues to extend its regulatory coverage. As European countries continue to work

75. de S.-O.-l'E. Lasser, supra note 44 , at 488.

76. Mattei \& Pardolesi, supra note 5, at 268-69. For example, a body of case law has been developed for nuisance law in France and product liability law in Germany. Id. at 269. 
together within the Union, they will need a common language to unite their regulatory efforts and objectives. Although the language of the law may differ among European countries, the "language of economics ... is . . . universal . . .."77 Moreover, although its structures were crafted in light of the more state-centered political systems of Europe, the European Union was founded on the idea of liberalizing markets among the Member States and has been supported by pro-market scholars. ${ }^{78}$ Given its foundations in market theory, it will be difficult for the European legal community to ignore the success of law and economics in analyzing the legal problems posed by the European Union.

The economic analysis of law may also enjoy more success in Europe as alternatives such as behavioral law and economics and socio-economics become more important in the law and economics movement. ${ }^{79}$ These alternatives to traditional neoclassical economic analysis consider limits to human rationality and group dynamics that may seem more realistic and appealing to European audiences. In considering the legal questions posed by societies that are organized more around the interaction of classes and groups in society, Europeans may find the analysis of socio-economics more compelling. Americans, too, are being drawn to these less traditional economic analyses in examining legal questions. ${ }^{80}$

While Europe currently lags significantly behind the United States in the economic analysis of law, it is possible for this gap to be reduced quickly. The success of the European Union may create the opportunity for economic analysis to succeed first with the European legislatures and then with the judiciary and academy. If the desire is there, the talented and highly skilled European academy can quickly assimilate this method of analysis. Moreover, because European judges are generally recruited directly from law school, if the legal academy were to develop a program of study in which economic principles were consistently taught, these concepts would quickly

77. Posner, supra note 3 , at 6 .

78. See, e.g., Claus Offe, The European Model of "Social" Capitalism: Can It Survive European Integration?, 11 J. POL. PHIL. 437 (2003).

79. See, e.g., ThOMAS Ulen \& RUSSEl KOROBKIN, COGNITION, RATIONALITY, AND THE LAW (forthcoming 2006); Russell B. Korobkin \& Thomas S. Ulen, Law and Behavioral Science: Removing the Rationality Assumption from Law and Economics, 88 CAL. L. REV. 1051 (2000); LynNe L. DAllas, LAW AND PUBlic POlicy: A SOCIOECONOMIC APPROACH (2005); Kenneth G. Dau-Schmidt, Economics and Sociology: The Prospects for an Interdisciplinary Discourse on Law, 1997 WIS. L. REV. 389 (1997).

80. Kenneth G. Dau-Schmidt, Pittsburgh, City of Bridges: Developing a Rational Approach to Interdisciplinary Discourse on Law, 38 LAw \& SOC'Y REV. 199, 201 (2004); Kenneth G. Dau-Schmidt, Law and Economics, in LEGAL SYSTEMS OF THE WORLD: A Political, Social, AND Cultural EnCYClopedia 856, 859-60 (Herbert M. Kritzer ed., 2002). 
enter the European judiciary. ${ }^{81}$

Although the law and economics movement in Europe currently suffers a fate similar to that of feral camels of the American Southwest, perhaps now that the camel's nose is under the tent, we will soon see more of this homely, yet useful, animal. 